\title{
Legitiem gebruik van de dicta probantia in de uiteenzettingen van de Dordtse Leerregels?
}

\author{
T.E. van Spanje
}

\begin{abstract}
Studies on the dicta probantia in the Canons of Dort often conclude that their use is unjustified. This article examines the dicta probantia derived from the NT and, within a particular hermeneutical context, suggests that they should be labeled dicta classica, even though the distinction is minimal. Further examination of these dicta supports the conclusion that their use sufficiently reflects their original meaning, and that therefore they function as relevant normative sources for the Canons of Dort.
\end{abstract}

\section{Intro en opzet}

In vergelijking met inhoudelijk-theologische studies over de Dordtse Leerregels $(D L)$ is er betrekkelijk weinig onderzoek naar het gebruik van de zogeheten dicta probantia ('bewijsplaatsen') in dit belijdenisgeschrift gedaan. ${ }^{1}$ In zijn boek over de $D L$ schrijft Verboom: 'Het voert te ver om afzonderlijk op de aard van deze dicta probantia in te gaan. Het zou wel de moeite waard zijn hier een afzonderlijke studie aan te wijden.'2 Op de keper beschouwd is het relatieve gebrek aan aandacht voor dit bijbelgebruik enigszins vreemd. Een gereformeerd belijdenisgeschrift dat is ontstaan binnen een traditie waarin de Bijbel zijn absoluut gezag heeft herkregen (verg. het adagium sola Scriptura), vraagt toch per definitie aandacht voor bijbelteksten en het gebruik ervan? Als er wel onderzoek naar dit bijbelgebruik wordt gedaan, dan zijn de resultaten overigens nogal eens negatief-kritisch (zie \$4). Kan dan nog wel worden gesteld, dat de $D L$ op een legitieme manier van de Bijbel gebruikmaken? Zouden wij, ongeveer vierhonderd jaar na dato, nog op dezelfde manier naar deze dicta probantia verwijzen?

1 Zie $\$ 3$ voor een alternatieve aanduiding voor dicta probantia.

2 W. Verboom, De belijdenis van een gebroken kerk: De Dordtse Leerregels - voorgeschiedenis en theologie, Zoetermeer 2005, 266 n. 130. Hier ook kritiek op het gebruik van diverse bewijsplaatsen in de $D L$. 
Binnen het kader van dit artikel is het uiteraard onmogelijk om het gebruik van alle dicta probantia te bestuderen. Om dit beknopte onderzoek af te bakenen wordt ervoor gekozen om alleen het bijbelgebruik in de 'thetische' gedeelten (uiteenzettingen) van de $D L$ te bestuderen. Alleen als in de 'antithetische' gedeelten (verwerpingen van de dwalingen) dezelfde dicta probantia worden gebruikt, dan worden ook deze gedeelten erbij betrokken.

In deze bijdrage wordt alleen het gebruik van bewijsplaatsen die aan het NT zijn ontleend, bestudeerd (zie ook $\$ 2$ ).

Allereerst worden de dicta probantia geïnventariseerd, met daarbij enkele opmerkingen ( $\$ 2)$. Vervolgens wordt het gebruik van deze bewijsplaatsen als zodanig geëvalueerd aan de hand van enkele hermeneutische opmerkingen (\$3). Daarna volgt een inhoudelijke evaluatie van het gebruik van het NT aan de hand van enkele exegetische opmerkingen $(\$ 4)$. Een conclusie sluit dit beknopte onderzoek af $(\$ 5)$.

\section{Inventarisatie}

De oorspronkelijk tekst van de $D L$ is 'met synodaal gezag in het Latijn en in een Nederlandse vertaling te Dordrecht in 1619 gedrukt.' ${ }^{3}$ Beide edities zijn opgenomen in de bekende en gedocumenteerde tekstuitgave van Bakhuizen van den Brink. ${ }^{4}$ Aan de hand van deze twee edities kan de onderstaande schematische inventarisatie van de dicta probantia worden gemaakt. Daarbij zijn de volgende richtlijnen aangehouden. ${ }^{5}$

(a) De bewijsplaatsen zijn geïnventariseerd naar aanleiding van (1) de expliciete verwijzingen in de Latijnse en Nederlandse editie, en (2) de annotaties/voetnoten in bovenstaande tekstuitgave.

(b) In de $D L$ wordt soms gerefereerd aan bijbelteksten zonder dat deze verwijsplaatsen in de Latijnse of Nederlandse uitgave (incl. de annotaties/ voetnoten) expliciet met een bijbelhoofdstuk en/of -vers worden aangeduid. ${ }^{6}$ Dergelijke verwijzingen staan niet in onderstaande inventarisatie, zodat deze in zekere zin niet volledig is. Indien men ook allerlei allusies en/of theolo-

3 J.N. Bakhuizen van den Brink, De Nederlandse Belijdenisgeschriften in authentieke teksten met inleiding en tekstvergelijkingen, Amsterdam 1976, 49.

4 Bakhuizen van den Brink, a.w., 225-287.

5 De bewijsplaatsen in de (Nederlandse) editie zijn uiteraard niet ontleend aan de Statenvertaling (SV) die immers van latere datum is, maar aan de Deux-Aesbijbel (DA) uit 1562. Zie ook Bakhuizen van den Brink, a.w., 52.

6 Een duidelijk voorbeeld is DL I, artikel 16, waar aan Jes. 42:3 (Mat. 12:20) wordt gerefereerd. 
gische sleutelwoorden ontleend aan de Bijbel zou verdisconteren, dan zou een inventarisatie uiteraard veel uitgebreider zijn. ${ }^{7}$

(c) Alle bewijsplaatsen staan telkens in volgorde van de Bijbel.

(d) Achter iedere bijbeltekst staat in vierkante haken een verwijzing naar de vindplaats in de $D L$. Aangezien in onderstaande inventarisatie reeds een onderscheid is gemaakt tussen de 'thetische' uiteenzettingen en de 'antithetische' verwerpingen, met vermelding van het desbetreffende hoofdstuk van de $D L$, volstaat een cijfer in vierkante haken. Dit cijfer verwijst dus naar een artikel c.q. verwerping.

\begin{tabular}{|c|c|c|}
\hline & Oude Testament & Nieuwe Testament \\
\hline \multicolumn{3}{|l|}{ Hoofdstuk I } \\
\hline Uiteenzetting & --- & $\begin{array}{l}\text { - Mat. 20:15 [DL 18] } \\
\text { - Joh. 3:16 [DL 2] } \\
\text { - Hand. 13:48 [DL 10]; 15:18 [DL 6] } \\
\text { - Rom. 3:19 [DL 1], 23 [DL 1]; 6:23 [DL 1]; } \\
\text { 8:30 [DL 7]; 9:11-13 [DL 10], 20 [DL 18]; } \\
\text { 10:14-15 [DL 3]; 11:33-36 [DL 18] } \\
\text { - Ef. 1:4 [DL 9], 4-6 [DL 7], 11 [DL 6]; 2:8 } \\
\text { [DL 5] } \\
\text { - Fil. 1:29 [DL 5] } \\
\text { - 1 Joh. 4:9 [DL 2] }\end{array}$ \\
\hline $\begin{array}{l}\text { Verwerping } \\
\text { dwalingen }\end{array}$ & - Deut. 10:14-15 [DL 9] & $\begin{array}{l}\text { - Mat. 11:21 [DL 9], 25-26 [DL 8]; 13:11 [DL } \\
\text { 8]; 24:24[DL 6] } \\
\text { - Luk. 10:20[DL 7] } \\
\text { - Joh. 6:39 [DL 6]; 15:16 [DL 5]; 17:6 [DL 1] } \\
\text { - Hand. 13:48 [DL 1 en 5] } \\
\text { - Rom. 8:30[DL } 2 \text { en 6], } 33[D L ~ 7] ; 9: 11^{8} \\
\text { [DL 5], } 18[D L ~ 8] ; 11: 6[D L 5] \\
\text { - Ef. 1:4 [DL } 1 \text { en 5]; 2:3-9 [DL 4] } \\
\text { - } 2 \text { Tim. 1:9 [DL 3] } \\
\text { - 1 Joh. 4:10 [DL 5] }\end{array}$ \\
\hline
\end{tabular}

7 In dat geval zou, naar aanleiding van $D L$ II, artikel 3, bijvoorbeeld ook 1 Joh. 2:2 in een inventarisatie moeten worden vermeld.

8 Bakhuizen van den Brink, a.w., 241 n. 2, verwijst naar twee verzen (Rom. 9:11-12). De versindeling van de DA is echter niet helemaal gelijk aan die van bijvoorbeeld de latere SV: het laatste gedeelte van Rom. 9:11 (SV) komt overeen met het begin van Rom. 9:12 (DA). Aangezien in de desbetreffende passage in de $D L$ volgens de SV het laatste gedeelte van Rom. 9:11 is bedoeld ('niet uit de werken, maar uit Hem Die roept'), wordt hier alleen Rom. 9:11 vermeld. In de Latijnse editie wordt dus niet de versindeling van de DA gebruikt. 


\begin{tabular}{|l|l|l|}
\hline Hoofdstuk II & & \\
\hline Uiteenzetting & --- & --- \\
\hline Verwerping & - Jes. 53:10 [DL 1] & - Joh. 10:15 [DL 7], 15,27 [DL 1]; 15:12-13 \\
dwalingen & & {$[D L 7]$} \\
& & - Rom. 3:24-25 [DL 4]; 8:33-349 [DL 7] \\
& & - Gal. 2:20 [DL 7] \\
& & - Ef. 2:3 [DL 5] \\
& & - Hebr. 7:22 [DL 2]; 9:15,17 [DL 2] \\
\hline
\end{tabular}

\begin{tabular}{|c|c|c|}
\hline Hoofdstuk III/I & & \\
\hline Uiteenzetting & --- & - Mat. 13 [DL 9] \\
\hline $\begin{array}{l}\text { Verwerping } \\
\text { dwalingen }\end{array}$ & $\begin{array}{l}\text { - Gen. 6:5 en 8:21 [DL 4] } \\
\text { - Ps. 51:19 [DL 4]; } \\
\text { 147:19-20[DL 5] } \\
\text { - Jes. 44:3 [DL 6] } \\
\text { - Jer. 17:9 [DL 3]; 31:18 } \\
\text { [DL 6]; 31:33 [DL 6] } \\
\text { - Ez. 36:26 [DL 7] }\end{array}$ & 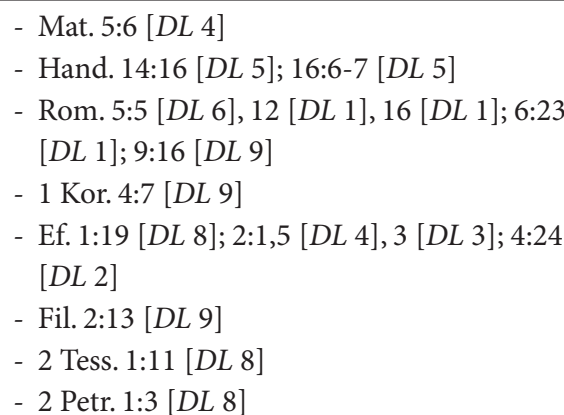 \\
\hline
\end{tabular}

\begin{tabular}{|c|c|c|}
\hline Hoofdstuk V & & \\
\hline Uiteenzetting & --- & $\begin{array}{l}\text { - Rom. 8:16-1710 [DL 10] } \\
\text { - } 1 \text { Kor. 10:13 [DL } 11]\end{array}$ \\
\hline $\begin{array}{l}\text { Verwerpingen } \\
\text { dwalingen }\end{array}$ & --- & $\begin{array}{l}\text { - Mat. 13:20 [DL 7] } \\
\text { - Luk. 8:13 [DL 7]; 22:32 [DL 9] } \\
\text { - Joh. 10:28-29 [DL 3]; 17:11,15,20 [DL 9] } \\
\text { - Rom. 5:8-911 [DL 3]; 8:32-3512[DL 1],39 } \\
\text { [DL 5]; 11:7 [DL 1] } \\
\text { - } 1 \text { Kor. 1:8 [DL 2] } \\
\text { - } 1 \text { Pet. 1:23 [DL 8] } \\
\text { - } 1 \text { Joh. 3:2-313 [DL 6], } 9[D L 3], 24^{14}[D L 5] ; \\
\text { 5:16-18 [DL 4] }\end{array}$ \\
\hline
\end{tabular}

Naar aanleiding van bovenstaande inventarisatie vallen enkele zaken op, zoals:

(1) In vergelijking met de andere uiteenzettingen heeft de uiteenzetting van $D L$ I ('Over de goddelijke verkiezing en verwerping') een groot aantal dicta probantia.

(2) Bij de uiteenzetting van DL II ('Over de dood van Christus en de verlossing van de mensen daardoor') worden er geen dicta probantia genoemd. 
(3) Verreweg de meeste dicta probantia komen voor in de 'verwerpingen van de dwalingen'.

(4) Er worden veel meer teksten uit het NT dan uit het OT als dicta probantia gebruikt. In de uiteenzettingen wordt zelfs nergens naar een tekst uit het OT verwezen. Daarentegen is er een relatief grote hoeveelheid oudtestamentische tekstverwijzingen in de 'verwerpingen van de dwalingen' van $D L$ III/IV. Het relatief grote aantal nieuwtestamentische teksten heeft uiteraard te maken met het feit dat het NT méér dan het OT over het thema vermeldt. ${ }^{15}$

(5) Met betrekking tot het NT bestaat er een behoorlijke spreiding van de dicta probantia: er wordt verwezen naar de Evangeliën, Handelingen, de Paulusbrieven en de Katholieke Brieven. Dicta probantia uit Openbaring komen niet voor; dit had uiteraard wel gekund (zie bijv. Op. 20:12,15; 21:27).

(6) Er wordt relatief veel van het Evangelie naar Johannes en het corpus Paulinum gebruikgemaakt.

(7) Een aantal dicta probantia wordt meer dan een keer genoemd: Mattheüs 13:20 (2x); Johannes 10:15 (2x); Handelingen 13:48 (3x); Romeinen 6:23 $(2 \mathrm{x}) ; 8: 30(3 \mathrm{x}), 33(3 \mathrm{x}), 34(2 \mathrm{x}) ; 9: 11(2 \mathrm{x})$; Efeziërs 1:4 (4x); 2:3 (3x), $5(2 \mathrm{x})$, $8(2 \mathrm{x})$. Efeziërs 1:4 is de enige tekst die maar liefst vier keer wordt gebruikt. Afgezien van het feit dat dit vers uiteraard relevant is voor het thema (zie

9 In de Latijnse editie wordt alleen naar Rom. 8:33 verwezen, terwijl Bakhuizen van den Brink, a.w., 251 n. 2, naar Rom. 8:33-34 verwijst. In de desbetreffende passage wordt, ook volgens de versindeling van de DA, inderdaad naar Rom. 8:33-34a verwezen.

10 De Latijnse editie verwijst expliciet naar Rom. 8:16-17, terwijl Bakhuizen van den Brink, a.w., 269, geen tekstverwijzing heeft. Volgens de versindeling van de DA zou een verwijzing naar Rom. 8:16 voldoende zijn geweest.

11 De Latijnse editie verwijst enkel naar Rom. 5:9, terwijl volgens de versindeling van de DA zeker ook een groot gedeelte van Rom. 5:8 wordt geciteerd. Bakhuizen van den Brink, a.w., 273 n. 4, verwijst terecht naar Rom. 5:8-9.

12 De Latijnse editie noemt alleen Rom. 8:32. Duidelijk is dat, volgens de versindeling van de DA, Rom. 8:32-35a wordt geciteerd (Bakhuizen van den Brink, a.w., 273 n. 2, verwijst naar Rom. 8:32-35).

13 De Latijnse editie vermeldt 1 Joh. 3:2-3 en de Nederlandse editie 1 Joh. 3:2. Naar aanleiding van de Nederlandse editie verwijst Bakhuizen van den Brink, a.w., 275 n. 4, naar beide verzen die inderdaad worden geciteerd.

14 De Latijnse versie heeft abusievelijk 1 Joh. 3:34, terwijl uiteraard 1 Joh. 3:24 wordt bedoeld.

15 Zie bijvoorbeeld Matthew Levering, Predestination: Biblical and Theological Paths, Oxford 2011, 13-35. 
\$4.3.3), kan een veelvuldige herhaling van dit vers ook worden verklaard uit het feit dat slechts ongeveer drie maanden voorafgaand aan de goedkeuring van de concepten, de voorman van de contraremonstranten (Gomarus) een uiteenzetting over Efeziërs 1:4-6 heeft gegeven. ${ }^{16}$

(8) Veel dicta probantia zijn geclusterd: relatief gezien komt het weinig voor dat binnen een artikel of verwerping slechts één bewijsplaats wordt genoemd.

(9) In verreweg de meeste gevallen bestaan de dicta probantia uit niet meer dan één bijbelvers.

Het is uiteraard veel te prematuur om reeds in deze paragraaf op grond van bovenstaande waarnemingen vergaande conclusies te trekken. Enkele waarnemingen worden wel in $₫ 3$ en $₫ 4$ verwerkt.

\section{Het gebruik van dicta probantia}

Sinds de beroemde inaugurele rede van Johann Philipp Gabler (1787, universiteit te Altdorf) waarin hij een strikte dichotomie tussen bijbelse en dogmatische theologie bepleitte, ${ }^{17}$ is er een al dan niet terechte 'theologische allergie' voor het gebruik van bewijsplaatsen in de dogmatiek ontstaan. Op het eerste gezicht wekt het gebruik van dicta probantia in een min of meer systematisch-theologisch betoog inderdaad een zekere argwaan. Het gevaar is immers niet denkbeeldig, dat met verwijzing naar een enkele bijbeltekst een eigen vooropgezette mening wordt beargumenteerd en met bijbels gezag wordt voorzien. In dat geval functioneren dicta probantia als een proof-text in negatieve zin. Kaiser en Silva geven een heldere definitie van proof-text:

A verse or longer passage used to prove a point or a doctrine. Although this method is not objectionable in principle (assuming that it reflects careful exegesis), the term often implies an approach that isolates a passage from its context and thus functions arbitrarily.18

Als slechts een enkele (korte) tekst als bewijsplaats wordt genoemd, dan dienen we nóg alerter te zijn. Immers, voor zo goed als iedere theologische

16 Verboom, De belijdenis van een gebroken kerk, 206.

17 Heikki Räisänen, Beyond New Testament Theology: A story and a programme, Londen 2000², 11-13.

18 Walter C. Kaiser jr. en Moisés Silva, Introduction to Biblical Hermeneutics: The Search for Meaning. Revised and Expanded Edition, Grand Rapids 2007, 336 (verg. 33). 
mening of visie is er wel een bijbeltekst te vinden ('elke ketter heeft zijn letter'). Het is echter een goede hermeneutische regel geen korte bijbelverzen een bijbelvers kan overigens moeilijk een 'tekst' worden genoemd - maar een teksteenheid of perikoop te exegetiseren. Dit voorkomt een 'atomistische' exegese van een bijbelvers waarbij geen rekening wordt gehouden met de relevante tekstuele context. Bovendien wordt de betekenis (meaning) van een teksteenheid pas gevonden, nadat het hele exegetische proces is doorlopen aan de hand van een verantwoorde hermeneutiek (zie hiervoor de handboeken). ${ }^{19}$

Gelden bovenstaande verwijten nu ook de $D L$ ? De vraag of de dicta probantia in de $D L$ onterecht zijn gebruikt bijvoorbeeld omdat aan deze teksten een betekenis onafhankelijk van hun context wordt toegekend (zie bovenstaande definitie van Kaiser en Silva), wordt pas in $₫ 4$ beantwoord. Hier kan allereerst worden vastgesteld, dat in de $D L$ relatief weinig één enkele tekst of één enkel tekstgedeelte wordt gebruikt binnen één artikel c.q. verwerping (zie opmerking (8) in \$2): in de $D L$ wordt de schijn vermeden, dat een uiteenzetting c.q. afwijzing van een dwaling met slechts één bijbeltekst kan worden beargumenteerd. Tegelijk is er sprake van een behoorlijke spreiding binnen het NT (zie opmerking (5) in \$2). Bovendien werden in de toenmalige gereformeerde traditie bijbelteksten nooit zomaar in een theologisch betoog gebruikt: aan het citeren van bijbelteksten was reeds een intensieve exegese voorafgegaan, waarbij uiteraard ook de context van een tekst was verdisconteerd. 'A text merely cited in the dogmatic systems may point toward a massive exegetical labor in commentaries and polemical treatises.' 20

Verder is het opvallend, dat het aantal dicta probantia tamelijk bescheiden is. Soms worden er zelfs helemaal geen teksten genoemd (\$2, opmerking (2)). Om ons slechts te beperken tot het corpus Paulinum: teksten als 1 Korintiërs 1:26-31 (in de verzen 27-28 gebruikt Paulus drie keer het deponente werkwoord eklegomai, 'uitverkiezen'), Kolossenzen 3:12 (eklektoi, 'uitverkorenen'), 1 Thessalonicenzen 1:2-4 (hè eklogè humoon, 'uw uitverkiezing', vers 4) en 2 Thessalonicenzen 2:13 (heilato humas ho theos, 'God heeft u verkoren') worden niet expliciet genoemd. De Synode van Dordrecht heeft blijkbaar geen uitputtend-gedetailleerde verkiezingsleer willen presenteren, maar alleen dat-

19 Zie ook William W. Klein, Craig L. Blomberg en Robert L. Hubbard jr., Introduction to Biblical Interpretation. Revised and Updated, Nashville 2004, 19-20.

20 Richard A. Muller, Post-Reformation Reformed Dogmatics: The Rise and Development of Reformed Orthodoxy, ca. 1520 to ca. 1725. Volume II: Holy Scripture: The Cognitive Foundation of Theology, Grand Rapids 20032, 509-520 [511]. 
gene aan de orde gesteld wat, gezien de historische setting, moest worden vermeld c.q. bestreden middels een evenwichtige ${ }^{21}$ samenvatting van de bijbelse hoofdlijnen: de $D L$ zijn wel uit de Schrift geput, maar daarmee is de Schrift zelf nog niet uitgeput. Daarom heeft de keuze van de dicta probantia wellicht ook te maken met de polemische debatten die aan de goedkeuring van de concepten zijn voorafgegaan. ${ }^{22} \mathrm{Het}$ is bijvoorbeeld niet vreemd dat op diverse plaatsen in de $D L$ wordt verwezen naar Romeinen 9 - ook al mag zo'n hoofdstuk sowieso niet ontbreken. Want reeds in 1593 waren er vragen naar aanleiding van Arminius' uitleg van dit hoofdstuk ontstaan. ${ }^{23}$ Hetzelfde geldt voor Efeziërs 1:4: in zijn Examen modestum libelli had ook Arminius hiervoor aandacht gevraagd. ${ }^{24}$

In de $D L$ wordt Efeziërs 1:4 diverse keren als separate tekst gebruikt. Voorafgaand aan de goedkeuring van de $D L$ heeft Gomarus een uiteenzetting over Efeziërs 1:4-6 gegeven (zie opmerking (7) in \$2). Ongetwijfeld heeft de synode ook de context bij dit separate vers laten meewegen, ook al is dit niet direct zichtbaar in de $D L$.

Ten slotte dient ook het 'geestelijke klimaat' van de tijd waarin de $D L$ zijn geschreven, te worden verdisconteerd. Luther had al de hermeneutische regel geformuleerd dat de Heilige Schrift sui ipsius interpres is. ${ }^{25}$ De Synode van Dordrecht heeft willen laten zien, dat niet het inzicht van de synode zelf maar de canones van de Schrift (!) doorslaggevend zijn (zie het Voorwoord en het Besluit van de $D L$ ). De dicta probantia worden dus niet zozeer gebruikt als bewijsplaatsen om 'het eigen gelijk te halen', maar veeleer om het signaal af te geven dat voor- én tegenstanders van de $D L$ zich aan het gezag van de Bijbel dienen te onderwerpen. Men heeft geen andere intentie dan het willen naspreken van de Schrift. Kortom: de gebruikte bijbelteksten in de $D L$ vormen geen legitimatie achteraf voor een reeds bestaande overtuiging, maar deze zijn een bron waaruit wordt geput voor uiteenzettingen c.q. verwerpingen van dwalingen (verg. 2 Tim. 3:16). Zo functioneert de Bijbel overigens ook in andere

21 Zie $\$ 2$, opmerking (5), waar wordt gewezen op de behoorlijke spreiding van de nieuwtestamentische teksten.

22 Zie de vele voorbeelden in onder meer Aza Goudriaan en Fred van Lieburg (red.), Revisiting the Synod of Dordt (1619-1619). Brill's Series in Church History 49, Leiden-Boston 2011.

23 Verboom, De belijdenis van een gebroken kerk, 21 en 27-29.

24 Verboom, a.w., 30-31.

25 WA 7.97.23. Er zouden nog andere vergelijkbare vindplaatsen in Luther kunnen worden gegeven. 
gereformeerde belijdenisgeschriften. ${ }^{26}$ Daarom zouden de (meeste) gebruikte bijbelteksten wellicht niet zozeer als dicta probantia moeten worden aangeduid, maar vooral als dicta classica om daarmee de functie van deze teksten binnen de $D L$ adequater te omschrijven: deze teksten bevatten algemene en context-overstijgende geldigheden omtrent een bepaald thema die kunnen (of zelfs moeten) worden gebruikt in een bijbels-theologische belijdenis omtrent datzelfde thema. Uiteraard zal dan nog wel moeten worden onderzocht of dergelijke teksten inderdaad als zodanig kunnen worden beschouwd (zie $\$ 4)$.

\section{Inhoudelijke evaluatie}

Worden de bijbelteksten in de uiteenzettingen van de $D L$ inderdaad op een juiste wijze gebruikt gezien de betekenis (meaning) van deze teksten? Uiteraard kunnen hier slechts enkele summiere exegetische opmerkingen worden gemaakt.

\subsection{Evangeliën}

Ten aanzien van de Evangeliën betreft het slechts twee verzen (Mat. 20:15 [DL I, artikel 18] en Joh. 3:16 [DL I, artikel 2]) en één hoofdstuk (Mat. 13 [DL III/IV, artikel 9]). In de gelijkenis over de arbeiders in de wijngaard (Mat. 20:1-16) geeft vers 15 aan, dat de heer van het huis vrij is om te doen wat hij wil. Ook al betreft de voorafgaande context niet uitverkiezing maar beloning (zie echter de tekstkritische discussie over polloi ... eklektoi, vers 16), toch is deze vrije wil van God een grondstructuur van de onverdiende verkiezing. Johannes 3:16 is (uiteraard) goed gebruikt en behoort tot de dicta classica die de liefde van God tot de 'wereld' (kosmos) beschrijven. De verwijzing naar de gelijkenis over de zaaier (Mat. 13:1-9) met de uitleg ervan (Mat. 13:18-23) wordt slechts gebruikt als vindplaats van datgene wat in het desbetreffende artikel is beschreven. Hetzelfde geldt voor $D L \mathrm{~V}$, verwerping 7, waar wordt verwezen naar Mattheüs 13:20.

\subsection{Handelingen}

In de uiteenzettingen wordt een keer naar Handelingen 13:48 verwezen (DL I, artikel 10). Dit vers kan bij uitstek worden gerangschikt onder de dicta classi-

26 Zie bijvoorbeeld M. te Velde (red.), Confessies: Gereformeerde geloofsverantwoording in zestiende-eeuws Europa, Heerenveen 2009, 12. 
$c a$ om het welbehagen van God aan te duiden als enige oorzaak van de genadige verkiezing. ${ }^{27}$ Daarom is deze tekst ook correct gebruikt om de dwalingen te verwerpen, dat er niet méér in de Schrift zou zijn geopenbaard dan dat God hen wil zalig maken die zullen geloven en volharden ( $D L I$, verwerping 1 ) en dat deze verkiezing het gevolg van vooruitgeziene vervulde voorwaarden zou zijn ( $D L \mathrm{I}$, verwerping 5).

Over de exegese van Handelingen 15:18 (DL I, artikel 6) bestaat discussie. In ieder geval is duidelijk dat dit vers staat in de context van Jakobus' betoog waarin aan de hand van een verwijzing naar Amos wordt aangetoond, dat God zich ook over de heidenen wil ontfermen en dat deze ontferming vastligt in Gods eeuwig raadsbesluit. Overigens is dit niet het enige vers dat in $D L \mathrm{I}$, artikel 6, wordt gebruikt (verg. \$2, opmerking (8), en \$3).

\subsection{Corpus Paulinum}

Wegens de beperkte ruimte wordt hier niet ingegaan op de vraag welke gevolgen het nieuwe perspectief op Paulus (The New Perspective on Paul) zou kunnen hebben voor de onderzoeksvraag in deze bijdrage.

\subsubsection{Romeinen}

In $D L \mathrm{I}$, artikel 1, zijn de verzen uit Romeinen 3 legitiem gebruikt: 3:19 (laatste gedeelte) en 3:23 duiden inderdaad de algemeenheid van de zonde en de vloek aan (verg. pas ho kosmos in 3:19, en pantes in 3:23). Beide verzen geven ook kerngedachten binnen de desbetreffende perikopen aan. In hetzelfde artikel wordt Romeinen 6:23 gebruikt: zoals in dit artikel met zoveel woorden wordt beleden, bestaat er een verdiende straf op de zonde. Op een vergelijkbare manier wordt ditzelfde vers ook in DL III/IV, verwerping 1, gebruikt.

In $D L \mathrm{~V}$, artikel 10, wordt terecht gerefereerd aan Romeinen 8:16-17 met betrekking tot de zekerheid van de uitverkiezing. In $D L \mathrm{I}$, artikel 7, worden gedachten uit Romeinen 8:30 slechts herhaald. In $D L \mathrm{I}$, verwerping 2, wordt naar Romeinen 8:30 verwezen om overtuigend te beargumenteren, dat de 'gouden keten van onze zaligheid' kan noch mag worden verbroken. Op een enigszins vergelijkbare manier functioneert deze tekst ook in $D L \mathrm{I}$, verwerping 6 (verkiezing tot zaligheid is volgens Paulus werkelijk onveranderlijk).

Romeinen 9:6-29 is een van de traditionele perikopen voor de (calvinistische) predestinatieleer en wordt daarom in de regel gerekend tot de dicta classica voor deze leer. Tegen dit gebruik van Romeinen 9 zijn echter minimaal

27 Bijvoorbeeld Thomas R. Schreiner, New Testament Theology: Magnifying God in Christ, Nottingham 2008, 140. 
twee bezwaren ingebracht: (1) in Romeinen 9 zou het niet gaan over redding maar over Israëls historische bestemming in het heilsplan van God, en (2) in Romeinen 9 zou er geen sprake zijn van individuele maar van corporatieve bestemming (van Israël). ${ }^{28}$ Echter, Schreiner stelt terecht dat het eerste bezwaar onder meer de context van Romeinen 9 miskent en de soteriologische terminologie van dit hoofdstuk negeert. ${ }^{29}$

Tegen het tweede bezwaar kan onder meer worden ingebracht, dat Paulus in deze perikoop vaak het enkelvoud gebruikt (Rom. 9:16, 18-19, 21). 'And it must also be said that the attempt to divide groups and individuals is logically flawed. Groups are made up of individuals... ${ }^{30}$ Romeinen 9 bespreekt uiteraard Israëls bestemming en er is inderdaad sprake van een heilshistorische benadering van Paulus. Maar tegelijk bevat dit hoofdstuk ook soteriologische terminologie die ook op het individu betrekking heeft. Beide bezwaren zouden overigens weleens het gevolg kunnen zijn van de door de exegeet gebruikte 'bril van het scopus-begrip' waardoor vertroebeling ontstaat: ${ }^{31}$ als de exegeet Romeinen 9 benadert aan de hand van de scopus 'Israëls plaats in de heilsgeschiedenis', dan veroorzaakt hij bij zichzelf leesblindheid voor 'individuele verkiezing tot redding'. In de uiteenzettingen van de $D L$ wordt overigens slechts twee keer naar Romeinen 9 verwezen: DL I, artikel 10 (Rom. 9:1113) en $D L$ I, artikel 18 (Rom. 9:20). Bovendien is Romeinen 9:20 zeer algemeen. In de verwerpingen wordt drie keer naar Romeinen 9 verwezen. In $D L$ I, verwerping 5, wordt het laatste gedeelte van Romeinen 9:11 geciteerd (volgens versindeling SV); hiermee wordt aangegeven dat de verkiezing helemaal van God afhangt ('niet uit de werken, maar uit de Roepende'). Romeinen 9:16 wordt in $D L$ III/IV, verwerping 9, terecht gebruikt om aan te geven, dat de (vermeende) vrije wil van de mens zelfs niet voor een deel de oorzaak van

28 Bijvoorbeeld Norman Geisler, Chosen But Free: A Balanced View of Divine Election, Minneapolis 1999, 82; William W. Klein, The New Chosen People: A Corporate View of Election, Grand Rapids 1990, 173-175 en Roger E. Olson, Against Calvinism, Grand Rapids 2011, 125.

29 Thomas R. Schreiner, Paul, Apostle of God's Glory in Christ: A Pauline Theology, Downers Grove 2001, 244-245.

30 Schreiner, Paul, 245. Zie ook Thomas R. Schreiner, 'Does Romans 9 Teach Individual Election unto Salvation?', in: Thomas R. Schreiner en Bruce A. Ware (red.), Still Sovereign: Contemporary Perspectives on Election, Foreknowledge, and Grace, Grand Rapids 2000, 89-106; Brian J. Abasciano, 'Corporate Election in Romans 9: A Reply to Thomas Schreiner', in: Journal of the Evangelical Theological Society 49.2 (2006), 351-371, en Thomas R. Schreiner, 'Corporate and Individual Election in Romans 9: A Response to Brian Abasciano', in: Journal of the Evangelical Theological Society 49.2 (2006), 373-386.

31 Vergelijk J.van Bruggen, Het lezen van de bijbel: Een inleiding, Kampen 1981, 37. 
bekering is. Romeinen 9:18 wordt in $D L \mathrm{I}$, verwerping 8 , eveneens terecht gebruikt om te laten zien, dat God besluiten neemt op grond van zijn (rechtvaardige) wil.

$D L I$, artikel 3, geeft een passende weergave van Romeinen 10:14-15 (verkondigers worden ingeschakeld), en zoals Paulus Romeinen 9-11 afsluit met een doxologie, zo sluit ook de uiteenzetting in $D L \mathrm{I}$, artikel 18, treffend met Romeinen 11:33-36 af.

\subsubsection{Korintiërs}

In $D L \mathrm{~V}$, artikel 11, wordt op een pastorale toon gezegd, dat de gelovigen niet altijd het volle geloofsvertrouwen en de zekerheid van de volharding ervaren. In dit verband wordt ter bemoediging naar 1 Korintiërs 10:13 verwezen. Dit vers staat bij Paulus echter wel in een andere context, namelijk: vermaning aan de hoogmoedige Korintiërs om niet te vallen. Tegelijk is het aannemelijk dat hij hier een algemene spreuk citeert, aangezien vers 13b twee hapax legomena binnen het corpus Paulinum heeft: eaoo ('toestaan') en ekbasis ('uitkomst'; verg. hupopheroo ['doorstaan'] dat bij Paulus verder alleen in 2 Tim. 3:11 voorkomt).

\subsubsection{Efeziërs ${ }^{32}$}

Het veelvuldige gebruik van Efeziërs 1:4 (zie ook \$2, opmerking (7)) ligt voor de hand: dit vers behoort tot de dicta classica in het corpus Paulinum bij het thema van de $D L .{ }^{33}$ Daarom wordt dit vers legitiem gebruikt in de redelijk algemene uiteenzetting van $D L \mathrm{I}$, artikel 7 (Ef. 1:4-6). Hetzelfde geldt voor $D L$ I, verwerping 1 , waar wordt verwezen naar dit vers om het brede bijbelse getuigenis recht te doen. In $D L \mathrm{I}$, artikel 9, wordt Efeziërs 1:4 nagesproken om het doel van de uitverkiezing te benadrukken. Hetzelfde vers wordt in $D L \mathrm{I}$, verwerping 5 , correct gebruikt om te weerspreken dat heiligheid een voorwaarde van verkiezing zou zijn. In Efeziërs 1:4 leert de apostel inderdaad een andere volgorde: God verkiest 'opdat wij heilig en smetteloos zouden zijn' (einai hèmas hagious kai amoomous; deze grammaticale constructie [infinitief met accusatief] geeft het doel van de uitverkiezing aan).

Tegen het gebruik van dit vers wordt overigens hetzelfde bezwaar inge-

32 Hier wordt uitgegaan van het paulinische auteurschap van Efeziërs. Zie de discussie bij D.A. Carson en Douglas J. Moo, An Introduction to the New Testament, Grand Rapids 2005², 480486.

33 Bijvoorbeeld Schreiner, Paul, 239-240. Hier wordt voorbijgegaan aan de min of meer dogmatische vraag of 'in Christus' voldoende gewicht in de $D L$ heeft gekregen. 
bracht als tegen het gebruik van Romeinen 9 (zie \$4.3.1). Olson, bijvoorbeeld, stelt: 'Ephesians 1, which speaks much about election, is not about individuals and their eternal destinies but about the people of God.' ${ }^{34}$ Zo ook Klein: 'The focus is not on the selection of individuals, but the group of those chosen.' 35 Ongetwijfeld gaat het in dit hoofdstuk over een collectief volk dat wordt gered (zie bijv. het herhaalde gebruik van hèmas ['ons']). Maar 'verlossing' (apolutroosis, 1:7), 'vergeving van overtredingen' (aphesis toon paraptoomatoon, 1:7), 'voorheen hopen op Christus' (proelpizoo en tooi Christooi, 1:12) en het door God 'verzegelen met de Geest' (sphragizoo tooi pneumati, 1:13) kunnen niet anders dan ook betrekking op de individuele gelovigen hebben. ${ }^{36}$

Het citaat uit Efeziërs 1:11 is kort (DL I, artikel 6), maar wel goed gekozen en niet atomistisch misbruikt (zie \$3): 'alle dingen doen naar de raad van Zijn wil' (ta panta energountos kata tèn boulèn tou thelèmatos autou) is een appositie (verg. tou) bij 'voorbestemd zijn naar een voornemen' (prooristhentes kata prothesin).

Nadat de inhoud van het vers is weergegeven, wordt in $D L \mathrm{I}$, artikel 5, Efeziërs 2:8 geciteerd (in $D L \mathrm{I}$, verwerping 4, wordt dit vers binnen een perikoop geciteerd). Volgens Geisler geeft dit artikel een verkeerde weergave van dit vers: het aanwijzend voornaamwoord 'dat' (touto, onzijdig) zou niet kunnen verwijzen naar 'geloof (pistis, vrouwelijk!), maar wel naar de zinsnede 'want u bent uit genade zalig geworden' (tèi gar chariti este sesooismenoi). ${ }^{37}$ Dit is onwaarschijnlijk, want een dergelijke exegese impliceert een tautologie (de zinsnede kai ... dooron als inhoudelijke herhaling van charis). Bovendien kan een dergelijk onzijdig aanwijzend voornaamwoord in het klassieke Grieks ook refereren aan de inhoud van het antecedent in algemene zin, ook als het antecedent mannelijk of vrouwelijk is. ${ }^{38}$

\subsubsection{Filippenzen}

In dezelfde uiteenzetting als waarin Efeziërs 2:8 wordt geciteerd (DL I, artikel 5) wordt ook naar Filippenzen 1:29 verwezen. Ook al is de gebruikte zinsnede ('het is u geschonken [echaristhè] in Hem te geloven') niet het hoofdthema

34 Olson, Against Calvinism, 125.

35 Klein, The New Chosen People, 179.

36 Bijvoorbeeld Schreiner, New Testament Theology, 344, met literatuurverwijzingen.

37 Geisler, Chosen But Free, 182-183, 212 en 228.

38 Zie bijvoorbeeld J.A.C. van Leeuwen, Paulus' Zendbrieven aan Efeze, Colosse, Filémon, en Thessalonika, Amsterdam 1926, 55-56, en L. Floor, Efeziërs: Eén in Christus, Kampen 1995, 98-99. 
van de perikoop (zie $\$ 4.3 .1$ over de 'bril van het scopus-begrip’), toch is deze zinsnede vergelijkbaar met Efeziërs 2:8.

\subsection{Katholieke Brieven}

In de uiteenzettingen van de $D L$ wordt slechts een keer naar de Katholieke Brieven verwezen, namelijk in $D L \mathrm{I}$, artikel 2. In dit artikel wordt de inhoud van 1 Johannes 4:9 slechts herhaald om de geopenbaarde liefde van God te beschrijven.

\section{Conclusie}

Er is veel voor te zeggen om te concluderen dat in de uiteenzettingen van de $D L$ de nieuwtestamentische teksten op een legitieme manier worden gebruikt. Om de gebruikte nieuwtestamentische teksten in de uiteenzettingen van de $D L$ te kwalificeren zou men, in plaats van de gangbare aanduiding dicta probantia, beter de aanduiding dicta classica kunnen gebruiken: ook al is de nuance tussen beide aanduidingen op het eerste gezicht miniem en worden beide aanduidingen vaak als synoniemen gebruikt, de tweede aanduiding laat beter uitkomen dat de opstellers van de $D L$ de Schrift niet als 'bewijsplaats voor het eigen gelijk' hebben gebruikt maar als bron en norm voor het belijden.

T.E. van Spanje is predikant van de hervormde wijkgemeente Sionskerk te Epe. 